\title{
АНАЛІЗ ІНСТИТУЦІЙНИХ ПЕРЕДУМОВ РОЗВИТКУ КОРПОРАТИВНОЇ СОЦІАЛЬНОЇ ВІДПОВІДАЛЬНОСТІ В УКРАÏHI
}

\section{ANALYSIS OF INSTITUTIONAL PREREQUISITES FOR THE DEVELOPMENT OF CORPORATE SOCIAL RESPONSIBILITY IN UKRAINE}

\author{
Кицюк Ірина Василівна \\ кандидат економічних наук, доцент, \\ Волинський національний університет імені Лесі Українки \\ ORCID: https://orcid.org/0000-0002-1519-5993 \\ Kytsyuk Iryna \\ Lesya Ukrainka Volyn National University
}

\begin{abstract}
У статті здійснено аналіз інституційних передумов розвитку корпоративної соціальної відповідальності в Україні. Зокрема, обґрунтовано необхідність розвитку корпоративної соціальної відповідальності як важливого інструменту досягнення сталого розвитку, а також проаналізовано основні активності та ініціативи у даній сорері на різних ієрархічних рівнях управління. Наголошується, що значну роль у розвитку корпоративної соціальної відповідальності в Україні відіграють міжнародні ініціативи, а також процес втілення курсу на продовження і поглиблення інтеграції до ЄС. Визначено ключові проблеми та перспективи розвитку корпоративної соціальної відповідальності в Україні в контексті світових тенденції, враховуючи той факт, що еволюція корпоративної соціальної відповідальності відбувається у відповідності з новими глобальними викликами до сталого розвитку.
\end{abstract}

Ключові слова: сталий розвиток, корпоративна соціальна відповідальність, соціальна відповідальність бізнесу, цілі сталого розвитку, Європейський Союз, Організація Об'єднаних Націй.

В статье осуществлен анализ институциональных предпосылок развития корпоративной социальной ответственности в Украине. В частности, обоснована необходимость развития корпоративной социальной ответственности как важного инструмента достижения устойчивого развития, а также проанализированы основные активности и инициативы в данной сфере на различных иерархических уровнях управления. Отмечается, что значительную роль в развитии корпоративной социальной ответственности в Украине играют международные инициативы, а также процесс воплощения курса на продолжение и углубление интеграции в ЕС. Определены ключевые проблемы и перспективы развития корпоративной социальной ответственности в Украине в контексте мировых тенденции, учитывая тот фракт, что эволюция корпоративной социальной ответственности происходит в соответствии с новыми глобальными вызовами к устойчивому развитию.

Ключевые слова: устойчивое развитие, корпоративная социальная ответственность, социальная ответственность бизнеса, цели устойчивого развития, Европейский Союз, Организация Объединенных Наций.

The main purpose of the article is to analyze the institutional preconditions for the development of corporate social responsibility in Ukraine. The actuality of the research might be explained by the fact that nowadays, more and more companies all over the world are interested in adhering to the principles and standards of corporate social responsibility in their business operations, which helps create own value for business, improve investment efficiency and returns, as well as increase the company's positive impact on society and environment as a whole. In particular, the article substantiates the need to develop corporate social responsibility as an important tool for achieving sustainable development; the main activities and initiatives in this sphere at different hierarchical levels of management are analyzed; as well as key problems and prospects for the development of corporate social responsibility in Ukraine in the context of global trends are identified, given the fact that the evolution of corporate social responsibility occurs in accordance with new global challenges to sustainable development. It is noted that the key role in the formation and development of corporate social responsibility in Ukraine is played by the International Community. Thus, great attention is paid to the consideration of United Nations initiatives for sustainable development; and also it is emphasized that a significant role in the development of corporate social responsibility belongs to Ukraine's Euro- 
pean integration process. However, the development of corporate social responsibility in Ukraine requires the active involvement of the state and business into this process. In addition, results of the researches show that corporate social responsibility is perceived not only as a reaction of enterprises to the emergence of various serious problems and challenges related, for example, with social inequality, environmental degradation, or increasing powerful of large corporations; as well as it represents an important guideline for the company's activities, that can help to better understand the needs and expectations of different stakeholder groups, which in turn will be reflected in the achievement of common values for the company and its stakeholders.

Keywords: sustainable development, corporate social responsibility, sustainable development goals, European Union, United Nations.

Постановка проблеми. В економічно розвинених країнах світу набула поширення практика корпоративної соціальної відповідальності (далі - КСВ), що стосується компаній, які беруть на себе відповідальність за власний вплив на суспільство. Зокрема, існує низка фракторів, що впливають на зростання кількості компаній, які впроваджують концепцію КСВ у свою діяльність: бажання зайняти гідну нішу на ринку, досягнення конкретного еоректу, уникнення певних ризиків, а також посилення конкурентного тиску, що стосується добрих практик КСВ, або ж посилення регулювання, чи саморегулювання у конкретній галузі щодо КСВ [1, с. 157-158]. Окрім того, як зазначає Колот А.: «Суспільство в цілому заінтересоване в тому, щоб кожна бізнес-структура набула статусу організації, орієнтованої на стійкий розвиток. У відповідь, «чимраз більша кількість бізнес-організацій сприймає КСВ не як примус або діяльність на злобу дня, а як корпоративну стратегію стійкого розвитку» [2, с. 4]. Відтак, втілення принципів сталого розвитку у корпоративних стратегіях та забезпечення їх практичної реалізації відбувається в контексті корпоративної соціальної відповідальності, а бізнес виступає одним із основних драйверів сталого розвитку економіки країни.

Аналіз останніх досліджень і публікацій. Беручи до уваги погляди експертів, практиків, а також науковців, що займаються дослідженням корпоративної соціальної відповідальності, варто зазначити, що зацікавленість компаній тематикою відповідального бізнесу продовжує зростати. Таким чином, незважаючи на нинішні занепокоєння щодо майбутнього КСB, реалізація визначених заходів продовжуватиметься, а запровадження певних керівних принципів або саморегулювання є неминучим.

Дослідженню питань теорії та практики корпоративної соціальної відповідальності присвячені численні праці таких вчених як Алухна М., Боуен Г., Грішнова О., Девіс. К., Друкер П., Керролл А., Колот А., Петрашко Л., Фріман Р., Фрідман М. та інших.
Виділення невирішених раніше частин загальної проблеми. На сьогодні вивчення передового світового досвіду щодо становлення та розвитку корпоративної соціальної відповідальності $€$ актуальним і значущим. Окрім того, слід наголосити на необхідності активного впровадження світових тенденції, ініціатив та передових практик, а також активізації зусиль урядових структур та бізнесу, що здійснюються у сорері КСВ в Україні.

Мета дослідження. Метою даної роботи $€$ здійснення аналізу інституційних передумов розвитку корпоративної соціальної відповідальності в Україні; а також виявлення ключових проблем та перспектив розвитку корпоративної соціальної відповідальності в Україні в контексті глобальних тенденцій у даній сорері.

Виклад основного матеріалу дослідження. Спочатку поняття «сталий розвиток» та «корпоративна соціальна відповідальність» використовувались взаємозамінно [3], але, прийнятий у 2010 р. Міжнародний стандарт ISO 26000:2010 "Керівництво із соціальної відповідальності” (англ., ISO 26000:2010 Guidance on social responsibility), що є ініціативою Міжнародноїорганізаціїзістандартизації(англ., International Organization for Standardization, ISO), визначив, що соціальна відповідальність зосереджена на організації (компанії) та пов'язана 3 відповідальністю за вплив іiі рішень та діяльності (включає продукти, послуги та процеси) на суспільство та навколишнє середовище через прозору та етичну поведінку, яка сприяє сталому розвитку, включаючи здоров'я та добробут суспільства; враховує очікування зацікавлених сторін (стейкхолдерів, від англ. stakeholders); відповідає чинному законодавству та міжнародним нормам поведінки; і інтегрована у діяльність організації та практикується у її взаємовідносинах (відносини стосуються діяльності організації в iї сорерах впливу) [4]. Таким чином, вважаємо, що поняття корпоративної соціальної відповідальності тісно пов'язане із поняттям сталого розвитку, згідно з яким компанії у всьому світі постають перед вимогою забезпечення 
добробуту та якості життя як теперішніх, так і майбутніх поколінь, а характер КСВ постійно змінюється, оскільки визначається реакцією підприємств на появу нових викликів до сталого розвитку. Що, у свою чергу, вимагає кардинально нового підходу до операційної та стратегічної діяльності підприємств.

1 січня 2016 року офріційно набули чинності 17 Цілей сталого розвитку (далі - ЦСР; англ., The 17 Sustainable Development Goals, SDGs) Порядку денного у сфері сталого розвитку на період до 2030 року (2030 Порядок денний; англ., 2030 Agenda), які фрормують загальні керівні принципи та стандарти для всіх країн у напрямку досягнення сталого розвитку [5].

Україна, будучи країною-членом Організації Об'єднаних Націй (далі - ООН; англ., United Nations, UN), також приєдналася до глобального процесу забезпечення сталого розвитку. Зокрема, протягом 2016-2017 рр. тривав широкомасштабний та всеосяжний процес адаптації Цілей сталого розвитку до ситуації в Україні, результатом якого стала національна система завдань та показників Цілей сталого розвитку, що забезпечує міцну основу для подальшого комплексного моніторингу країни. Так, національні завдання, індикатори для моніторингу їх виконання, а також цільові орієнтири, встановлені для досягнення до 2030 року, відображено в Національній доповіді “Цілі сталого розвитку: Україна" [6]. Загалом, 17 цілей та 86 національних завдань інкорпоровані у 145 нормативно-правових актів Уряду, визначено 1052 завдання та 3465 заходів, закріплених у зазначених актах [7]. Окрім того, для подальшої імплементації та забезпечення моніторингу і оцінки стану досягнення ЦСР дорученням Кабінету Міністрів України утворено Міжвідомчу робочу групу з питань координації процесів імплементації та забезпечення моніторингу ЦСР, до складу якої входять заступники міністрів, керівники агенцій ООН, науковці [8]. Слід наголосити, що 21 серпня 2019 р. Уряд підтримав ініціативу Мінекономрозвитку та ухвалив розпорядження, яким впорядкував правила збору даних для моніторингу реалізації Цілей сталого розвитку в Україні [9], а 30 вересня 2019 р. Президент України видав Указ "Про Цілі сталого розвитку України на період до 2030 року" [10], в якому підтримав забезпечення досягнення глобальних цілей сталого розвитку та результатів їх адаптації 3 урахуванням специфріки розвитку України, викладених у Національній доповіді “Цілі сталого розвитку: Україна" [7].
Варто зазначити, що як особлива ініціатива Генерального секретаря ООН, Глобальний Договір Організації Об'єднаних Націй (англ., UN Global Compact) - це заклик до компаній будувати свою діяльність та стратегію на основі десяти універсальних принципів у галузі прав людини, праці, навколишнього середовища та боротьби з корупцією. Створений у 2000 р., мандат Глобального Договору ООН полягає в керівництві та підтримці глобальної ділової спільноти у просуванні цілей та цінностей ООН завдяки відповідальній корпоративній практиці. Налічуючи більше ніж 12 тисяч комерційних компаній (включаючи малий та середній бізнес) та понад 3 тисячі небізнесових організацій, що базуються в 162 країнах світу, - це найбільша ініціатива корпоративно відповідальних активних учасників [11]. Глобальний Договір ООН включає 69 Локальних Мереж (англ., United Nations Global Compact Local Network), що становлять собою багатосторонні платфрорми, які працюють безпосередньо з бізнесом, допомагаючи у реалізації Десяти принципів Глобального Договору ООН та досягненні цілей сталого розвитку. Завдяки знанням щодо місцевих та регіональних особливостей, Локальні Мережі допомагають компаніям зрозуміти, що означає відповідальний бізнес у відповідних національних, культурних та мовних контекстах. Локальні Мережі Глобального Договору підтримують як місцеві фрірми, так і дочірні компанії транснаціональних корпорацій у впровадженні Десяти принципів Глобального договору ООН та виконанні вимог стосовно щорічної звітності. Діяльність кожної Локальної Мережі базується на місцевих пріоритетах та потребах, поєднуючи різноманітні заходи та проєкти [12].

Мережа Глобального Договору Організації Об'єднаних Націй в Україні (далі - Мережа) є офріційним представником Мережі Глобального Договору ООН та була заснована за підтримки Представництва ООН в Україні в 2006 році. Мережа об'єднує компанії та інші зацікавлені сторони, що впроваджують у свою діяльність Десять принципів Глобального Договору $\mathrm{OOH}$ та виступає транслятором ЦСР. Мережа $є$ діалоговою платсрормою розвитку корпоративної соціальної відповідальності в Україні та підтримує український бізнес в пошуку інноваційних рішень для вирішення екологічних та соціальних проблем. Мережа Глобального Договору ООН в Україні проводить заходи, що підсилюють партнерську взаємодію свідомих бізнесів, пропонує своїм членам великий вибір 
навчальних подій, підтримку в написанні Звітів з прогресу, інфрормаційне сприяння, ознайомлює $з$ найкращими практиками з реалізації КСВ в міжнародному контексті, надає можливість впливу на політику з розвитку КСВ в Україні та ін. [11; 13, с. 4].

Слід зазначити, що протягом останніх років спостерігається тенденція збільшення кількості учасників Мережі. Зокрема, найбільша кількість наявних учасників, що приєдналися до Мережі Глобального Договору в Україні спостерігається з 2019 року. Так, згідно з інфрормацією офріційного сайту Глобального Договору $\mathrm{OOH}$, станом на початок липня 2021 р. нараховується 70 учасників Мережі [12], серед яких: суб'єкти бізнесу, громадські організації, вищі навчальні заклади, профрспілки та органи влади (локальний рівень). Що свідчить, у свою чергу, про наявність діалогу бізнес-держава-експерти-суспільство щодо сталого розвитку та корпоративної соціальної відповідальності.

15 березня 2017 р. було підписано Угоду між Урядом України та Організацією економічного співробітництва та розвитку (далі- ОЕСР; англ., Organisation for Economic Co-operation and Development, OECD) щодо приєднання до Декларації про міжнародне інвестування та багатонаціональні підприємства (далі - Декларація ОЕСР) [14], Керівних рекомендацій для багатонаціональних компаній та процедурних рішень Ради ОЕСР [15]. "Керівні Принципи ОЕСР для багатонаціональних підприємств" (англ., OECD Guidelines for Multinational Enterprises) [16], що були прийняті урядами держав ОЕСР в 1976 р. та переглянуті в 2011 р. (містять жорсткіші стандарти корпоративної поведінки), $€$ невід'ємною частиною Декларації ОЕСР та визначають принципи добровільної дії та стандарти відповідальної ділової поведінки відповідно до законодавства і $є$ визнаними у світі [17]. Це допомагає Україні запроваджувати міжнародні стандарти здійснення інвестиційної діяльності та соціальної відповідальності бізнесу [15].

Впровадження та моніторинг виконання Керівних принципів ОЕСР здійснюється за допомогою Національного контактного пункту, який утворено в кожній державі, що приєдналася до Декларації ОЕСР. В Україні діє Національний контактний пункт. Зокрема, Наказом Міністерства економічного розвитку і торгівлі України від 28.02.2018 р. № 283 утворено міжвідомчу робочу групу щодо забезпечення фрункціонування Національного контактного пункту з питань сприяння наданню рекомендацій (керівних принципів) для багатонаціональних підприємств у рамках Декларації ОЕСР про міжнародне інвестування та багатонаціональні підприємства при Мінекономіки [17].

У січні 2019 року Міністерство юстиції розпочало роботу над імплементацією Керівних принципів ООН у сорері бізнесу та прав людини в Україні [18]. "Керівні принципи ООН у сорері бізнесу та прав людини" (англ., The UN Guiding Principles on Business and Human Rights) були одноголосно схваленими Радою ООН з прав людини (англ. The United Nations Human Rights Council, UNHRC) y 2011 p. Варто зазначити, що Керівні принципи ООН щільно співвідносяться із 17 Цілями сталого розвитку та становлять набір керівних принципів для держав та компаній щодо запобігання та подолання порушень прав людини, здійснених в ході чи внаслідок діяльності суб'єктів господарювання [19]. Зокрема, з метою визначення фрактичного стану дотримання в Україні Керівних принципів ООН у сорері бізнесу та прав людини було проведено Національне оцінювання базових показників з питань бізнесу і прав людини. В результаті зазначеного Національного оцінювання були виявлені прогалини в законодавстві й державній політиці та невідповідності практик ведення бізнесу стандартам корпоративної відповідальності у ссрері прав людини, що вказують, передусім, на нестачу скоординованої урядової політики у ссрері бізнесу та прав людини. Низка проблем, виявлених у таких сорерах як працевлаштування, охорона навколишнього природного середовища, протидія дискримінації, оподаткування, охорона здоров'я та безпека, протидія корупції, взаємодія з громадою та ін. свідчить про брак застосування заснованого на правах людини підходу у фрормуванні державних політик у відповідних сорерах та практиках ведення бізнесу [20].

Оскільки Україна $\epsilon$ членом Міжнародної організації праці (далі - МОП; англ., International Labour Organisation, ILO) та ратифрікувала більшість чинних конвенцій МОП, Україна має поважати також засади "Тристоронньої декларації принципів стосовно багатонаціональних підприємств та соціальної політики" Міжнародної організації праці (англ., International Labour Organisation's Tripartite Declaration of Principles concerning Multinational Enterprises and Social Policy, MNE Declaration), прийнятої в 1977 р., зі змінами та доповненнями, внесеними у 2000 р. та у 2006 р. та переглянутої в 2017 році [21]. 
Вагоме місце у розвитку корпоративної соціальної відповідальності в Україні відіграє процес втілення курсу на продовження і поглиблення інтеграції до ЄС. Зокрема, у статті 422 Угоди про Асоціацію між Україною та ЄС, ратифрікованої Законом України від 16.09.2014 р. № 1678-VII, зазначається, що сторони сприятимуть корпоративній соціальній відповідальності та підзвітності, а також заохочуватимуть відповідальну ділову практику, що пропагується такими міжнародними організаціями як ООН, МОП, ОЕСР [22]. Також законодавство ЄС вимагає від великих компаній розкривати певну інфрормацію про те, у який спосіб вони здійснюють свою діяльність та управляють соціальними та екологічними викликами (Директива 2014/95/ EU щодо розкриття нефрінансової інфрормації; англ., Directive 2014/95/EU on non-financial reporting). Зокрема, починаючи із 2018 p. компанії зобов'язані включати нефрінансові показники у свої річні звіти. Крім того, у червні 2017 р. Європейська Комісія оприлюднила рекомендації (Керівні принципи Європейської Комісії щодо нефрінансової звітності; англ., Guidelines on non-financial reporting (methodology for reporting non-financial information) C/2017/4234) [23], які включають методологію звітності нефрінансової інфрормації, щоб допомогти компаніям розкривати інорормацію щодо екологічних та соціальних складових їхньої діяльності. Дані рекомендації не є обов'язковими, і компанії можуть на власний розсуд обирати яких рекомендацій дотримуватися: міжнародних, Європейського Союзу, або ж національних, враховуючи власні характеристики та особливості бізнессередовища.

Зокрема, у рамках гармонізації українського законодавства із європейським, у 2019 р. середні та великі підприємства України вперше подавали звіти про управління за 2018 р., що, у свою чергу, значно підвищило кількість звітів в Україні серед ТОП-100 великих компаній [24], проте, аналіз наявних звітів підкреслює необхідність більш ретельного підходу та відповідального ставлення до процедури звітування.

Окрім того, 21 квітня 2021 р. Європейська Комісія прийняла амбіційний та всеохоплюючий пакет заходів, що сприяють покращенню фрінансування сталої діяльності в межах усього Європейського Союзу [25]. Таке рішення надає можливість інвесторам переорієнтувати інвестиції у більш сталі технології та бізнес, сприяючи переходу до кліматично нейтральної Європи до 2050 року. Також даний крок сприятиме перетворенню $Є С$ на світового лідера у встановленні стандартів сталого фрінансування. Що, у свою чергу, відкриває нові можливості та перспективи у даній сорері і для України.

Зокрема, розвитку сталого фрінансування в Україні значно сприяє Міжнародна фрінансова корпорація (МФК; англ. International Finance Corporation, IFC), - підрозділ Групи Світового банку.

Важливим кроком у розвитку корпоративної соціальної відповідальності стало також схвалення 24 січня 2020 р. Кабінетом Міністрів України Концепції реалізації державної політики у сорері сприяння розвитку соціально відповідального бізнесу в Україні на період до 2030 [17].

Значну роль у розвитку КСВ в Україні відіграє Центр "Розвитку КСВ", що є експертною організацією, яка просуває принципи сталого ведення бізнесу та соціальної відповідальності в Україні; об'єднує компанії, адвокатує розвиток КСВ на національному рівні, а також спільно з бізнесом і донорами впроваджує сталі КСВ-проєкти задля системних змін в Україні [26].

Щодо практики впровадження КСВ то, слід зазначити, що, незважаючи на те, що протягом 2014-2019 рр. основною формою КСВ в Україні були благодійні ініціативи [17], національний бізнес перестав ототожнювати корпоративну соціальну відповідальність із благодійністю. Компанії намагаються активно впроваджувати КСВ, інтегруючи соціальні та екологічні питання у свою операційну діяльність, на основі взаємодії зі стейкхолдерами. Великі національні компанії, або ж дочірні компанії і фрілії, що функціонують в Україні, також розробляють та впроваджують стратегії КСВ. Окрім того, інвестори та фрінансисти піклуються про показники корпоративної відповідальності більше, ніж будь-коли, вважаючи, що це здійснює суттєвий вплив на прибутковість підприємства.

Слід відмітити, що пандемія коронавірусу COVID-19 також підкреслила необхідність гнучкості та важливість зв'язку між бізнесом та суспільством у відповідь на виклики, ризики та загрози, пов'язані з масштабними суспільними проблемами, що особливо актуально на тлі нерівномірних реакцій уряду.

Варто зазначити, що визначальними для розвитку корпоративної соціальної відповідальності в Україні, є світові тенденції щодо сталого розвитку [27]: інтерес до інвести- 
цій $з$ урахуванням етики та ESG-критеріїв (environmental, social, governance - екологічних, соціальних та управлінських) - інтегрування ESG-критеріїв у фрінансові рішення; важливість людського капіталу; реагування на кліматичні зміни; захист навколишнього природного середовища; побудова стійких та гнучких ланцюгів поставок; забезпечення стійкого споживання та виробництва; застосування технологій для забезпечення сталого розвитку; захист основних прав людини; використання важелів бізнесу для фрормування політики та нормативно-правових актів щодо підтримки сталого розвитку; просування капіталізму стейкхолдерів.

Проте, незважаючи на перспективи, які виникають в контексті зазначених глобальних тенденцій, існує низка внутрішніх проблем, зумовлених суспільно-політичною нестабільністю, наявними структурними, галузевими й регіональними диспропорціями, наслідками економічного спаду, що негативно впливають на розвиток корпоративної соціальної відповідальності в Україні. Окрім того, процес розвитку КСВ в Україні потребує більш активної участі держави, яка визначає розвиток соціально відповідального бізнесу одним із пріоритетів державної політики [17], а також усві- домлення бізнесом своєї ключової ролі, яку він може і повинен відігравати у забезпеченні сталого розвитку в цілому.

Висновки. Таким чином, аналіз інституційних передумов розвитку корпоративної соціальної відповідальності в Україні дозволяє зробити наступні висновки:

- до основних ієрархічних рівнів управління, що тією чи іншою мірою визначають розвиток КСВ можна віднести наступні: глобальний (міжнародний), національний, регіональний, локальний (організаційний) та особистісний;

- серед суб'єктів КСВ варто виділити міжнародні організації та транснаціональні корпорації, державу, органи державної влади та органи місцевого самоврядування, суб'єкти господарювання, інститути громадянського суспільства, освітні установи, наукові та експертні організації, окрему людину;

- інституціональні рамки розвитку корпоративної соціальної відповідальності в Україні в цілому визначаються міжнародними правовими нормами та національною нормативнозаконодавчою базою;

- розвиток КСВ в Україні відбувається в контексті глобальних тенденцій щодо сталого розвитку і вимагає активного залучення та взаємодії держави та бізнесу.

\section{СПИСОК ВИКОРИСТАНИХ ДЖЕРЕЛ:}

1. Kytsyuk I., Pavlikha N. Społeczna odpowiedzialność biznesu a zrównoważony rozwój gospodarki Ukrainy na tle doświadczeń międzynarodowych. Przedsiębiorstwo, gospodarka i społeczeństwo w kręgu zainteresowania ekonomistów / red. nauk. Ryszard Kamiński. Poznań : Polskie Towarzystwo Ekonomiczne Oddział w Poznaniu, 2020. S. 157-173.

2. Колот А. Сучасна фрілософрія корпоративної соціальної відповідальності: еволюція поглядів. Україна: аспекти праці. 2013. № 8. C. 3-17. URL: http://nbuv.gov.ua/UJRN/Uap_2013_8_3

3. Jastrzębska E. Biznes na rzecz rozwoju zrównoważonego - dobre praktyki / Business for sustainable development - good practices. Ekonomia XXI wieku / Economics of the 21st century. 2016. 4(12). S. 36-37.

4. ISO 26000:2010(en) Guidance on social responsibility. ISO. URL: https://www.iso.org

5. Transforming our world: the 2030 Agenda for Sustainable Development. United Nations. URL: https://sdgs.un.org

6. Національна доповідь 2017 “Цілі сталого розвитку: Україна”. Міністерство економіки України. URL: https://me.gov.ua

7. Цілі сталого розвитку та Україна. Урядовий портал. URL: https://www.kmu.gov.ua

8. Міністерство економічного розвитку і торгівлі України. Політика, що ґрунтується на фрактах, для досягнення Цілей сталого розвитку: стале житлове господарство та міський розвиток України. UNECE. URL: https://unece.org

9. Уряд затвердив показники для моніторингу реалізації Цілей сталого розвитку. Урядовий портал. URL: https://www.kmu.gov.ua

10.Про Цілі сталого розвитку України на період до 2030 року. Верховна Рада України. Законодавство України. URL: https://zakon.rada.gov.ua

11. Глобальний Договір ООН в Україні. Global Compact Network Ukraine. URL: https://globalcompact.org.ua

12. Our Participants. United Nations Global Compact. URL: https://www.unglobalcompact.org

13. Зінченко А. Г., Саприкіна М. А. Корпоративна соціальна відповідальність: 2005-2010: стан та перспективи розвитку. Київ : Ви-во «Фарбований лист», 2010. 56 с. 
14. OECD Declaration on International Investment and Multinational Enterprises. OECD Legal Instruments. URL: https://legalinstruments.oecd.org

15. Міжнародні стандарти інвестиційної діяльності та відповідальної бізнес-поведінки. Національний контактний пункт Україна. URL: https://ncp.gov.ua

16. OECD Guidelines for Multinational Enterprises, 2011 Edition. OECDiLibrary. URL: https://www.oecd-ilibrary.org

17.Про схвалення Концепції реалізації державної політики у ссрері сприяння розвитку соціально відповідального бізнесу в Україні на період до 2030 року. Верховна Рада України. Законодавство України. URL: https://zakon.rada.gov.ua

18. Мін'юст розпочав роботу над імплементацією керівних принципів ООН у ссрері бізнесу та прав людини в Україні. Міністерство юстиції. URL: https://minjust.gov.ua

19. The UN Guiding Principles on Business and Human Rights. An introduction. United Nations Human Rights Office of The High Commissioner. URL: http://www.ohchr.org

20. Резюме Національного оцінювання базових показників у сфері бізнесу та прав людини в Україні. Міністерство юстиції. URL: https://minjust.gov.ua

21. Tripartite Declaration of Principles concerning Multinational Enterprises and Social Policy (MNE Declaration) 5th Edition (2017). International Labour Organization. URL: http://www.ilo.org

22. Association Agreement between the European Union and its Member States, of the one part, and Ukraine, of the other part, OJ L 161, 29.5.2014, p. 3-2137. EUR-Lex. URI : https://eur-lex.europa.eu

23. Non-financial reporting. European Commission. URL: https://ec.europa.eu

24. Саприкіна М. Навіщо бізнесу звіти зі сталого розвитку. Економічна правда. Четвер, 31 жовтня 2019.

URL: https://www.epravda.com.ua

25. Sustainable finance package. European Commission. URL: https://ec.europa.eu

26. CSR Ukraine. URL: https://csr-ukraine.org

27. What's Next for Sustainable Business? 2021 Sustainability Trends. The SustainAbility Institute by ERM. URL: https://www.sustainability.com

\section{REFERENCES:}

1. Kytsiuk, I., \& Pavlikha, N. (2020). Sotsialna vidpovidalnist biznesu ta stalyi rozvytok ekonomiky Ukrainy na tli mizhnarodnoho dosvidu [Social responsibility of business and sustainable development of Ukraine's economy against an international experience background]. In R. Kaminski (Eds.), Pidpryiemstvo, ekonomika ta suspilstvo sered interesiv ekonomistiv - Enterprise, economy and society among economists' interests, pp. 157-173. Poznan: Filiia v Poznani Polskoho Ekonomichnoho Tovarystva.

2. Kolot, A. (2013). Suchasna filosofiia korporatyvnoi sotsialnoi vidpovidalnosti: evoliutsiia pohliadiv [Modern philosophy of corporate social responsibility: the evolution of views]. Ukraina: aspekty pratsi - Ukraine: aspects of work, 8, 3-17. Retrieved from: http://nbuv.gov.ua/UJRN/Uap_2013_8_3 (in Ukrainian)

3. Yastshembska, E. (2016). Biznes dlia staloho rozvytku - dobri praktyky [Business for sustainable development - good practices]. Ekonomika 21 stolittia - Economics of the 21st century, 4(12), 36-37. http://doi.org/10.15611/ e21.2016.4.03

4. ISO 26000:2010(en) Guidance on social responsibility. ISO. Retrieved November 15, 2017. Retrieved from: https://www.iso.org

5. Transforming our world: the 2030 Agenda for Sustainable Development. United Nations. Retrieved July 21, 2021. Retrieved from: https://sdgs.un.org

6. Natsionalna dopovid 2017 "Tsili staloho rozvytku: Ukraina" [National Report 2017 "Sustainable Development Goals: Ukraine"]. Ministerstvo ekonomiky Ukrainy - Ministry of Economy of Ukraine. Retrieved from: https://me.gov.ua

7. Tsili staloho rozvytku ta Ukraina [Sustainable Development Goals and Ukraine]. Uriadovyi portal - Government portal. Retrieved from: https://www.kmu.gov.ua

8. Polityka, shcho gruntuietsia na faktakh, dlia dosiahnennia Tsilei staloho rozvytku: stale zhytlove hospodarstvo ta miskyi rozvytok Ukrainy [Evidence-based policy to achieve Sustainable Development Goal: sustainable housing and urban development in Ukraine]. UNECE. Retrieved from: https://unece.org

9. Uriad zatverdyv pokaznyky dlia monitorynhu realizatsii Tsilei staloho rozvytku [The Government has approved indicators to monitor the implementation of the Sustainable Development Goals]. Uriadovyi portal - Government portal. Retrieved July 7, 2021. Retrieved from: https://www.kmu.gov.ua

10. Pro Tsili staloho rozvytku Ukrainy na period do 2030 roku [About the Sustainable Development Goals of Ukraine for the period up to 2030]. Verkhovna Rada Ukrainy. Zakonodavstvo Ukrainy - Verkhovna Rada of Ukraine. The Legislation of Ukraine. Retrieved from: https://zakon.rada.gov.ua 
11. Hlobalnyi Dohovir OON v Ukraini - Global Compact Network Ukraine. Retrieved from: https://globalcompact.org.ua

12. Our Participants. United Nations Global Compact. Retrieved from https://www.unglobalcompact.org

13. Zinchenko, A. H., \& Saprykina, M. A. (2010). Korporatyvna sotsialna vidpovidalnist: 2005-2010: stan ta perspektyvy rozvytku [Corporate social responsibility: 2005-2010: state and prospects of development]. Kyiv: Vy-vo Farbovanyi lyst. (in Ukrainian)

14. OECD Declaration on International Investment and Multinational Enterprises. OECD Legal Instruments. Retrieved from: https://legalinstruments.oecd.org

15. Mizhnarodni standarty investytsiinoi diialnosti ta vidpovidalnoi biznes-povedinky [International standards for investment activity and responsible business behavior]. Natsionalnyi kontaktnyi punkt Ukraina - National contact point Ukraine. Retrieved from: https://ncp.gov.ua

16. OECD Guidelines for Multinational Enterprises, 2011 Edition. OECDiLibrary. Retrieved from: https://www.oecd-ilibrary.org

17. Pro skhvalennia Kontseptsii realizatsii derzhavnoi polityky u sferi spryiannia rozvytku sotsialno vidpovidalnoho biznesu v Ukraini na period do 2030 roku [On approval of the Concept for the implementation of state policy in the field of promoting the development of corporate social responsibility in Ukraine for the period up to 2030]. Verkhovna Rada Ukrainy. Zakonodavstvo Ukrainy - Verkhovna Rada of Ukraine. The Legislation of Ukraine. Retrieved from: https://zakon.rada.gov.ua

18. Miniust rozpochav robotu nad implementatsiieiu kerivnykh pryntsypiv OON u sferi biznesu ta prav liudyny v Ukraini [The Ministry of Justice has begun work on the implementation of the UN Guiding Principles on Business and Human Rights in Ukraine]. Ministerstvo yustytsii - The Ministry of Justice of Ukraine. Retrieved from: https://minjust.gov.ua

19. The UN Guiding Principles on Business and Human Rights. An introduction. United Nations Human Rights Office of The High Commissioner. Retrieved from: http://www.ohchr.org

20. Reziume Natsionalnoho otsiniuvannia bazovykh pokaznykiv u sferi biznesu ta prav liudyny v Ukraini [Executive Summary of the National Baseline Assessment on Business and Human Rights in Ukraine. Executive summary]. Ministerstvo yustytsii - The Ministry of Justice of Ukraine. Retrieved from: https://minjust.gov.ua

21. Tripartite Declaration of Principles concerning Multinational Enterprises and Social Policy (MNE Declaration) - 5th Edition (2017). International Labour Organization. Retrieved from: http://www.ilo.org

22. Association Agreement between the European Union and its Member States, of the one part, and Ukraine, of the other part, OJ L 161, 29.5.2014, 3-2137. EUR-Lex. Retrieved from: https://eur-lex.europa.eu

23. Non-financial reporting. European Commission. Retrieved from: https://ec.europa.eu

24. Saprykina, M. (2019). Navishcho biznesu zvity zi staloho rozvytku [Why is Sustainability Reporting important for Business]. Ekonomichna Pravda - Economic Truth, Chetver, 31 zhovtnia - Thursday, October 31. Retrieved from: https://www.epravda.com.ua (in Ukrainian])

25. Sustainable finance package. European Commission. Retrieved from: https://ec.europa.eu

26. CSR Ukraine. Retrieved May 20, 2020. Retrieved from: https://csr-ukraine.org

27. What's Next for Sustainable Business? 2021 Sustainability Trends. The SustainAbility Institute by ERM. Retrieved from: https://www.sustainability.com 